\title{
The UK Overseas Territories: A decade of progress and prosperity?
}

\section{Peter Clegg}

Department of History, Philosophy and Politics

University of the West of England, Bristol

Email: peter.clegg@uwe.ac.uk

Peter Gold

Department of English, Linguistics and Communication

University of the West of England, Bristol

Email: peter.gold@uwe.ac.uk

The article analyses the relationship between the United Kingdom and its Overseas Territories since the publication of the 1999 White Paper Partnership for Progress and Prosperity. The article considers the efforts by the UK government to improve links with the territories via a new partnership based on mutual obligations and responsibilities. The article focuses on the two most important aspects of the White Paper - governance and economic growth and sustainability. Much has been achieved, but fundamental structural problems in the relationship remain unattended. The article concludes by recommending how the relationship can be improved over the coming years.

Keywords: Overseas Territories, good governance, human rights, economic sustainability, offshore finance

\section{Introduction}


This study analyses the complex relationship between the United Kingdom (UK) and its permanently populated Overseas Territories (OTs) with a particular focus on the last decade up to the British general election of May 2010. In 1999 the 'New' Labour government published a White Paper, Partnership for Progress and Prosperity, which was an attempt to refocus and renew the links between the UK and its OTs. For many years before the relationship was rather ad hoc - a situation that can be traced back to the compromises, fudges and deals characteristic of 'pragmatic' British colonial administration. The paper details the efforts on the part of the Labour government to overcome the legacy of only intermittent UK interest, through the imposition of greater coherence across the territories via a new partnership based on mutual obligations and responsibilities. It focuses on the two most important aspects of the White Papergovernance (including good governance, constitutional reform and human rights) and economic growth and sustainability. An assessment is made of the progress acheived in these areas since 1999 and the problems that remain. The concluding section provides a number of recommendations in terms of how the relationship can be improved over the next ten years.

\section{A mandate for reform}

A crisis in Montserrat and a UK National Audit Office (NAO) report highlighted Britain's inadequate organisational and regulatory framework as it related to the then named Dependent Territories in the mid-1990s. The crisis in Montserrat began in July 1995 (towards the end of the British Conservative Party's term in office) when the Soufrière Hills Volcano erupted, precipitating a period of great uncertainty and 
insecurity for the island. The eruption of the volcano devastated the country and by December 1997 almost 90 per cent of the resident population of over 10,000 had been relocated at least once, while over two-thirds had left the island. Much of the infrastructure had been destroyed or put out of use, while the private sector had collapsed and the economy had become largely dependent on British aid (DFID, 1999). Three reports were published on the disaster, all of which highlighted several deficiencies in the UK-Montserrat relationship, including a confused division of responsibility for Montserrat between the Department for International Development (DFID) and the Foreign and Commonwealth Office (FCO), the overly complex UK government management systems for Montserrat and the absence of contingency planning in terms of how the FCO and DFID would manage an emergency in a Dependent Territory (International Development Committee, 1997 and 1998, and DFID, 1999).

At about the time the Montserrat crisis was at its height and the first reports on the situation were being published, the NAO investigated the action taken by the FCO to minimise the risk of potential contingent liabilities falling on the UK as a result of the actions of the territories. As the report stated: 'Given the Foreign Office's responsibilities, there exists a continuing exposure to potential liabilities ... Under English and Dependent Territory law, the governments of the Territories are answerable for their own actions. However, if the Territories' resources are insufficient, the UK government may come under pressure to provide assistance. Legal liability may fall on 
the UK if Territories fail to comply with international law, especially treaty obligations' (NAO, 1997: 1).

The report found that despite the FCO having undertaken a number of past initiatives to identify and minimise the risk of contingent liabilities in the territories, the UK remained exposed. In particular the NAO noted that the UK was vulnerable from 'financial sector failures, corruption, drug trafficking, money laundering, migrant pressure and natural disasters' (1997: 7). The NAO worryingly described the UK government as having 'extensive responsibilities but limited power' (1997: 17). In a follow-up report by the House of Commons Committee of Public Accounts its concern over the situation was starkly highlighted. The Committee wrote: 'We are worried by the mismatch between the extent of these responsibilities [for the Dependent Territories] and the inadequacy of the FCO's powers, strong in theory but limited in practice, to manage them'. The Committee further stated: 'As a result of this mismatch, the UK taxpayer continues to be exposed to very significant liabilities in the Territories and, from time to time, these materialise. More generally, we are concerned at the Foreign Office's admission that everything is not wholly under control and that all risks are not weighed and properly covered' (Committee of Public Accounts, 1998: v). Both the NAO and the Committee recommended a number of reforms to reduce Britain's potential contingent liabilities and encouraged the UK government to strengthen its control over the territories.

\section{Partnership for Progress and Prosperity: a new beginning}


The arrival of the 'New' Labour government, the ongoing crisis in Montserrat and the NAO and Committee of Public Accounts reports, led to the initiation of a review of the UK's relationship with its OTs in August 1997. The purpose of the review was 'to ensure that the relationship reflected the needs of the Territories and Britain alike and to give the Territories confidence in our commitment to their future' (FCO, 1999: 8). It was based on the principle that 'Britain's links to the Dependent Territories should be based on a partnership, with obligations and responsibilities for both sides' (idem). In particular, it was noted, 'the relationship ... needs to be effective and efficient, free and fair. It needs to be based on decency and democracy' (FCO, 1999: 7). During the review the UK government consulted with a range of interested parties but it was clearly a British led initiative.

In March 1999 the completed review was published as a White Paper entitled Partnership for Progress and Prosperity (FCO, 1999). The White Paper set out a number of recommendations on issues such as the constitutional link, citizenship, financial standards, good governance and human rights. The latter issues highlighted Britain's desire that the territories should meet certain standards set by the UK government and the wider international community. On the constitutional issue the White Paper reported that there was a clear wish on the part of the territories to retain their connection with Britain and not move towards independence. However, it was agreed that a process of constitutional review would be carried out in an attempt to update existing provisions and that if any territory wanted independence in the future Britain would not stand in its way. Further, the White Paper documented the changes 
that had been introduced to streamline the administrative links between the UK and the territories, including for the first time a dedicated minister for the territories and the establishment of a new department within the FCO (the Overseas Territories Department). Also, a new political forum, the Overseas Territories Consultative Council, was established to bring together British ministers and territory representatives to discuss matters of concern.

Most of the reforms were undertaken out of public view, but two gained widespread publicity and perhaps best represented the UK government's new approach to the territories. One decision related to a change in nomenclature from 'Dependent Territory' to 'Overseas Territory'. Several officials from the territories had asked for the name change believing that it better reflected the nature of a post-colonial 'partnership' at the end of the twentieth century. Many of the territories at this point were not receiving any budgetary assistance from the UK (today only Montserrat, Pitcairn and St Helena, which all have significant natural and structural barriers to growth, receive such assistance) and they felt, therefore, that they were not dependent on the UK government. The second change to the relationship came with the announcement that British citizenship - and so the right of abode - would be offered to citizens of all of the territories (hitherto only the Falkland Islanders and Gibraltarians had enjoyed such status).

The review of the OTs undertaken by the British Labour government was certainly the most wide-ranging for many years. The desire of a new administration to assert its 
influence over a problematic policy area, as the OTs were deemed to be, was an important factor underpinning the FCO-led examination. In addition, the fact that the Labour Party had been out of power for 18 years heightened the expectations of new thinking and new approaches. In many ways the outcome of the Partnership for Progress and Prosperity White Paper indicated that the Labour government was serious about its attempts to overcome long-standing problems in the UK-OT relationship. However, as will be seen, the realities of overseeing such a disparate and in most cases distant group of territories have meant that only some aspects of the Partnership for Progress and Prosperity agenda have been fulfilled. Indeed, it is evident from particular developments that fundamental structural problems in the relationship remain unattended.

\section{Governance}

In the White Paper there was a clear commitment to the promotion of good governance, democracy and the rule of law. Further, the White Paper highlighted a series of action points to achieve these ends, including through measures to promote more open, transparent and accountable government; to improve the composition of legislatures and their operation; to improve the effectiveness, efficiency, accountability and impartiality of the public service; to promote representative and participative government; and to secure freedom of speech and information (FCO, 1999: 13). The record of achievement in these areas is patchy, and was undermined significantly by the serious allegations of corruption highlighted recently in the Turks and Caicos Islands (TCI). The case is certainly not representative of the OTs as a whole, but the deep-seated problems in the 
TCI must be acknowledged because they highlight grave failures in the post-1999 approach to UK-OT relations. The weaknesses in governance were seen most starkly in regard to the TCI, but it can be argued they exist more generally in the relationship. To illustrate the point the situation in the TCI must be considered.

\section{The Turks and Caicos Islands}

A detailed picture of the state of affairs in the TCI was revealed by a Commission of Inquiry led by Sir Robin Auld, a former British High Court Judge. The Commission was appointed on 10 July 2008, an interim report was completed in late February 2009 and the full report was released five months later on 18 July. Sir Robin's criticisms were numerous, but fundamentally he argued that 'there is a high probability of systemic corruption in government and the legislature and among public officers in the TCI ...' (TCI Commission of Inquiry, 2009: 11).

Particular areas of concern included the '... bribery by overseas developers and other investors of Ministers and/or public officers, so as to secure Crown (public) land on favourable terms, coupled with government approval for its commercial development'; the '... serious deterioration ... in the Territory's systems of governance and public financial management and control'; the '... concealment of conflicts of interest at all levels of public life, and consequent venality'; the manipulation and abuse of Belongerships (a status which confers rights normally associated with citizenship, including the right to vote and to be a recipient of the disposal of Crown land); and the misuse of wide discretionary powers given to Ministers in the 2006 Constitution (TCI 
Commission of Inquiry, 2009: 11-12). Stemming from these and many other criticisms Sir Robin recommended the institution of criminal investigations in relation to former Premier Michael Misick (who resigned in March 2009 after the Commission's interim report was published) and three of his former cabinet ministers.

The criticisms and recommendations against high profile members of the government were, of course, highly damaging, but what was perhaps even more significant was the Commission's emphasis on the systemic nature of the corruption. Throughout the Commission's report fundamental weaknesses in the system of governance in the TCI were highlighted. The outcome was that the TCI's ' $\ldots$ democratic traditions and structures [were] tested almost to beyond breaking point' (TCI Commission of Inquiry, 2009: 215). Because of these broader concerns Sir Robin called for '... urgent and wideranging systemic change' (TCI Commission of Inquiry, 2009: 218) and in particular the partial suspension of the 2006 Constitution, interim direct rule from Westminster and reforms to the Constitution and other aspects of the system of governance in the TCI to help prevent future abuses of power (TCI Commission of Inquiry, 2009).

After such wide ranging criticisms the UK government had little choice but to act. As former FCO minister, Gillian Merron, stated after the Commission's interim report was published: 'These are some of the worst allegations that I have ever seen about sitting politicians ...' and '... when things go badly wrong ... we need to act' (Hansard, 2009a). An Order in Council, the Turks and Caicos Islands Constitution (Interim Amendment) Order 2009, was implemented on 14 August 2009. Once executed, the 
Order suspended ministerial government and the House of Assembly for a period of up to two years (although this has since been extended). In their place the Governor was given the power to take charge of government matters, subject to instruction from the FCO, supported by a range of other British officials and guided by an Advisory Council and Consultative Forum, both of which are composed entirely of Belongers (FCO, 2009). Soon after an anti-corruption team was dispatched to the TCI to investigate and prosecute criminal cases arising out of the Commission's report (Financial Times, 2009).

One other aspect of the Commission of Inquiry's report which has not yet been touched upon is the parallels it draws with the Inquiry undertaken by Louis Blom-Cooper in 1986 into allegations of arson, corruption and related matters in the TCI (Report of the Commissioner, 1986). Blom-Cooper's findings are disturbingly similar to those of the 2009 Inquiry, when he talks about 'persistent unconstitutional behaviour' and 'maladministration by both Ministers and civil servants at every level of government', leading to "constant blights upon a ... society which is already displaying signs of political instability' and to an economy that 'at present is precariously poised' (Report of the Commissioner, 1986: 98-99). Commenting on these observations, the report of the 2009 Inquiry states that '[Blom-Cooper's] general conclusions ... suggest that little has changed over the last 20 or so years leading to this Inquiry, except as to the possible range and scale of venality in public life' (TCI Commission of Inquiry, 2009: 23). This remark is deeply troubling and is perhaps the most significant aspect of the entire report 
as it strikes right at the heart of UK government policy in relation to many of its OTs, not just the TCI, over the last decade and indeed beyond.

There had in fact been strong indications for many years that there were deep-rooted problems in the TCI. Numerous studies were undertaken that highlighted issues of concern (TCI Commission of Inquiry, 2009: 94-95). As the Commission of Inquiry report argued: '... [criticisms] have been identified time and again in official and independent reports in different contexts ... but to little result' (TCI Commission of Inquiry, 2009: 102). The FCO was certainly aware of some of the problems in the TCI and it did upgrade the post of the governor, but largely it took a softly, softly approach to enacting change. Further, the FCO was not proactive in investigating the allegations of more systemic corruption that were coming to the fore. Indeed, until very late in the day the FCO argued there was insufficient evidence to justify either prosecutions or a Commission of Inquiry regarding developments in the TCI (Foreign Affairs Committee, 2008: 67). The UK government's position may have remained the same if it had not been for a Foreign Affairs Committee (FAC) investigation on the OTs.

The largest number of submissions received by the FAC came from the TCI, and many of the authors had taken the unusual step of asking for confidentiality. During the course of the investigation the committee said that many of these submissions suggested 'a substantial measure of financial impropriety [is] taking place', including, it was claimed, at government level (Caribbean Insight, 2008: 1). The subsequent report also criticised the 'climate of fear' in the territory, with some citizens too afraid to discuss 
their concerns about the standards of governance in the TCI. Under such circumstances the FAC recommended that the UK government establish a commission of inquiry, with full protection for witnesses (Foreign Affairs Committee, 2008: 7).

While recognising that it is sometimes difficult to assess whether an issue is serious enough to merit intervention, the FAC report stated quite clearly that in regards to the TCI '[the UK government's] approach has been too hands off'. As a consequence, the Committee argued, 'the Government must take its oversight responsibility for the Overseas Territories more seriously - consulting across all Overseas Territories more on the one hand while demonstrating a greater willingness to step in and use reserve powers when necessary on the other' (2008: 131). The call for a Commission of Inquiry indicated how seriously the committee viewed the situation in the TCI, and a few days later the UK government announced that one would be established. Despite this final act the TCI's collapse in governance suggests that rather than being too interventionist as some of its critics would suggest, the UK government has been far too lax in its dealings with at least some of the OTs and thus many of the original objectives of the 1999 White Paper have not been met - in the TCI's case, clearly so.

\section{The balance of power in UK-OT relations}

The breakdown of good governance in the TCI shows that the UK government failed to meet its own objectives as defined by the White Paper. However, was the TCI an isolated case or is there a more general problem with UK oversight of - and good governance in - the OTs? It can certainly be argued that Misick and his government 
pushed the system of governance to breaking point and behaved in an unacceptable manner. In contrast there have been allegations of corruption in several other OTs, such as in relation to the Bermuda Housing Corporation, but these appear to have been more isolated (FAC, 2008). So it does appear that standards of governance are relatively good in the other territories. However, there are several underlying problems in the UK's relationship with its OTs that might indicate that its failings are more deep-seated than just in relation to the TCI.

Each constitution allocates government responsibilities to the Crown (i.e. the UK government and the governor) and the OT, according to the nature of the responsibility. Those powers generally reserved for the Crown include defence and external affairs, as well as responsibility for internal security and the police, international and offshore financial relations and the public service. The Crown also has responsibility for the maintenance of good governance. Meanwhile, individual territory governments have control over all aspects of policy that are not overseen by the Crown, including the economy, education, health, social security and immigration. However, ultimate control rests in the hands of the UK as the territories are constitutionally subordinate (Davies, 1995). Nevertheless, because the arrangements were not intended to be permanent rather were they originally 'stepping-stones on the route to independence' (Taylor, $2005,21)$ - there are problems.

In terms of the direct relationship the UK government, via the governors, is reluctant to use its full powers, even in areas where the governor has responsibility - rather 
consensus and persuasion are preferred. The UK is aware of the importance of maintaining good relations with democratically elected governments and this is particularly true when OTs are no longer in receipt of UK government funding - as is the case with most of them at present. A further constraint in advancing the good governance agenda is the limited power the governor has in certain circumstances. There remains a problem with issues that are in the mid-spectrum. Of course, the governor can use his constitutional powers - including Commissions of Inquiry - and the UK government can introduce Orders in Council, but there is a reluctance to do this because of the controversy they cause. As has been argued, 'Governors have few intermediate levers between ... influence on the one hand and the constitutional power on the other, despite the responsibilities they must discharge' (NAO, 2007: 26). Problems can be exacerbated because key UK responsibilities depend on funding from local governments which is not always sufficient. Also, governors often lack the experience and skills to carry-out this very particular and difficult role, meaning they have to learn on the job and make decisions which may not always be appropriate. Further, the views and priorities of the governor and those of the FCO can diverge. In consequence concerns that are serious but not extremely so are sometimes left unattended and allowed to fester or are dealt with inappropriately. Another issue is that the constitutions provide continuous opportunities for turf wars between the governor and local ministers. As Taylor argues: 'In my time in Montserrat Ministerial attempts to encroach on the Governor's areas of responsibility and to challenge his powers were the normal stuff of day-to-day administration as they are to a greater or lesser extent in all the Territories' (Taylor, 2000: 339). Tensions are made worse by the fact that the 
British government and the local government have different agendas and face conflicting pressures. Local governments are subject to short-term electoral pressures, while the UK government is concerned with maintaining good governance and minimising its contingent liabilities.

Problems also exist in Whitehall, particularly in terms of continuity of personnel and the limited resources available for the promotion of good governance. In terms of staffing, both at ministerial and civil service level, there is little continuity. There was a highturnover of individuals filling the post of Parliamentary Under-Secretary of State under Labour - six between 1999 and 2010. Further, the ministerial position, as well as dealing with the OTs, involved several other responsibilities as part of the portfolio, including the EU, Eastern Europe and Russia, South America, and Australasia and Pacific. Within this list the OTs were certainly not central priorities. In addition, the qualifications of the people filling the ministerial role have sometimes been inadequate. Some of the deficiencies at ministerial level have also been replicated within the civil service. For example, the OTs team has had six heads in 12 years, while FCO desk officers for the territories tend to remain in post for 18 months to two years, reflecting general practice in the FCO and across Whitehall (NAO, 2007). As the NAO argued ‘...the resulting lack of continuity and loss of Territory-specific knowledge has been a concern for some stakeholders' (NAO, 2007: 28). A final important concern is the limited funds the FCO has available to encourage good governance and to build capability in the OTs. For example, the department was only able to provide $£ 215,000$ in 2006/07 for improvements that extended across all the OTs (NAO, 2007: 68). 
At the level of the OTs most are faced with governance challenges that relate to their small size. For example, 'close communities with personal or extended family relationships between officials and citizens, and small legislatures with a lack of separation of duties and membership between the executive and the elected assembly' (NAO, 2007: 31). Further, some lack a developed civil society and a vibrant media, both of which can reduce the level of checks and balances on the executive. In addition the very limited electoral franchise in many OTs, particularly in the Caribbean, helps to distort the political and democratic process. The source of this problem is the special immigration status that exists, called 'Belonger', which only applies to certain members of the permanent resident population. Those that have 'Belonger' status have the right to vote; other residents do not. As a consequence the franchise is much restricted. For example, in the TCI prior to the partial suspension of the constitution only about 7,000 people were allowed to vote out of a total population of 36,000 and these 7,000 were spread across 15 constituencies, the smallest of which had 190 voters. There is evidence to suggest that Misick's Progressive National Party (PNP) took advantage of the limited franchise to win power (TCI Commission of Inquiry, 2009: 79).

\section{Constitutional review and human rights}

Before concluding this section on governance it is necessary to consider two other issues that emanated from the White Paper: constitutional reform and the requirement of the territories to reform and modernise their human rights provisions. On the first issue the UK government maintained that reform should be evolutionary and during 2001 set 
in motion a constitutional review process for the OTs. For the first time the process was supposedly 'locally owned and driven rather than directed from London' (Foreign Affairs Committee, 2004: 7). Despite this the UK had clear lines beyond which reform was not possible unless independence was the end objective. In a memorandum submitted on 27 October 2003 by the FCO Minister Bill Rammell to the FAC, strict limits were placed on territories' constitutional room for manoeuvre. The final sentence of the memorandum stated: 'OT governments should not expect that in the Constitutional Reviews ... the UK will agree to changes in the UK Government's reserved powers, or which would have implications for the independence of the judiciary and the impartiality of the civil service' (Foreign Affairs Committee, 2004: 9). Whereas Gibraltar and the Falkland Islands can both now claim 'post-colonial' constitutions - in the sense that both the administering power and the territory agree that the responsibilities set out in the constitution have resulted in a relationship that is no longer a colonial one - in the constitutions agreed recently for British Virgin Islands, Cayman Islands, St Helena (plus Ascension and Tristan da Cunha), Pitcairn and TCI only limited new responsibilities were devolved to the territories. However, even these changes further exacerbated rather than addressed the structural and operational problems in the UK-OT relationship considered above. Indeed, the new TCI constitution introduced in 2006 actually helped to facilitate the breakdown in good governance that occurred. As the Commission of Inquiry stated: 'The 2006 Constitution, to a far greater extent than its 1988 predecessor, leaves individual Cabinet Ministers with a wealth of discretions, by way of grants, exemptions, concessions, 
discounts etc. to override or side-step matters of principle or orderly and fair administration' (2009: 216).

With regard to the issue of human rights, the UK government made clear that 'high standards of observance' were required (FCO, 1999: 20). The White Paper indicated three particular issues on which the UK government wanted reform: judicial corporal punishment, capital punishment and legislation outlawing homosexual acts between consenting adults in private. Progress was made on the first two issues but the issue of decriminalising homosexuality was more problematic. Despite lengthy consultations there remained strong resistance to decriminalisation. Many in the territories believed the issue was a local one and local views and predispositions should take precedence over British demands. However, in early 2001, despite widespread controversy the UK government passed an Order in Council to force the change in legislation. It is interesting to note, however, that although the law was changed the view of many has not and in some territories (for example Bermuda and Gibraltar) local differences remain, with the age of consent for male homosexuals remaining higher than for other citizens.

Since then the FCO, sometimes in collaboration with DFID, has maintained an interest in human rights in the OTs, which includes an objective to extend all the key human rights conventions to the OTs. In addition the UK government has responsibility for ensuring that the OTs fulfil their obligations from the conventions which have been extended to them. To assist in this process DFID is funding a $£ 1$ million four-year 
programme to build human rights capacity in the OTs (FAC, 2008: 82). Some real progress was made when in their new constitutions Gibraltar, the Falkland Islands, British Virgin Islands, Cayman Islands, TCI, and St Helena included sections protecting human rights. However, even here there is disappointment. Concerns have been raised about an aspect of the new Cayman Islands constitution - the narrow scope of section 16 dealing with non-discrimination (The Cayman Islands Constitution Order, 2009: 1718). Human Rights Watch (HRW) criticised the language highlighting the absence of a free-standing guarantee of equality before the law and the limitation of antidiscrimination protections only to rights expressly included in the constitution (Human Rights Watch, 2009). Furthermore section 16 limits the scope of protection to discrimination by the government - thus horizontal discrimination by private entities is not forbidden. Hence it is likely that the new constitution will be inadequate to properly safeguard the rights of certain groups within society. Indeed it was alleged that the scope of section 16 was narrowed by the Cayman government at the last moment after representations were made by religious and other civil society groups. The intention was to deny protections to lesbian, gay, bisexual and transgender people (Human Rights Watch, 2009). The result is that the Cayman Islands new constitution is likely to be at variance with its commitments under various UN conventions and the European Convention on Human Rights and Fundamental Freedoms. Such a situation is unfortunate in its own terms, but it also reflects badly on the UK as it is ultimately responsible if the OTs are not fulfilling their obligations. 
If all these issues are brought together there is certainly more than a nagging suspicion that despite the changes enacted under the White Paper problems of oversight and engagement continue. One former FCO official has suggested that HMG still treats the OTs 'as being mostly of peripheral interest' (FAC, 2008: 131). Weaknesses in Whitehall, exacerbated by a loss of institutional memory through the high-turnover of ministers and civil servants and the restricted powers of governors, can and do have a serious detrimental impact on policy. This is, of course, important, as proper UK oversight is vital in territories where institutional capacity, developed civil society, strong legislatures and vibrant media are lacking. Nevertheless, the structure and dynamics of the UK-OT relationship seem just about adequate when there is good faith and responsibility on both sides. When the system of governance is really tested, however, as in the case of the TCI, the imbalances and weaknesses in the system are starkly highlighted and standards of governance can deteriorate quite significantly.

\section{Economic growth and sustainability}

Beyond the political sphere the White Paper focused on the need to improve the regulation of the offshore financial service industries in the OTs and to encourage sustainable economic development, in part by improving financial procedures and controls via, for example, improved auditing and financial accountability (FCO, 1999: $6,25)$. As with the political issues considered above progress on the economic agenda has been variable and there has been a degree of complacency on the part of HMG, particularly in relation to the sustainability of certain OT economies. Consideration of this aspect of the White Paper comes later, but first an assessment is made as to whether 
the commitment to improve the regulation of the offshore financial service industries has been achieved.

\section{Offshore financial services}

The offshore financial sector is extremely important to the economies of many OTs both in terms of GDP and employment. For example, in the Cayman Islands over 50 per cent of GDP is derived from offshore financial services and a quarter of all employment. Bermuda, British Virgin Islands and Gibraltar also have significant interests in the sector, while Anguilla and TCI have a more modest interest (Foot, 2009: 24). Each territory provides a particular niche service: Bermuda is the third largest centre for reinsurance in the world and the second largest captive insurance domicile, Cayman Islands is the world's leading centre for hedge funds, while British Virgin Islands is the leading domicile for international business companies (Foot, 2009: 16). Notwithstanding, concerns have been raised about the probity of the offshore financial sector. A key source of criticism came in 1997 from the NAO report on contingent liabilities. The report concluded that the offshore sector was vulnerable to abuses by money launderers and drug traffickers and the territories faced possible financial sector failure as a consequence (NAO, 1997). In response the UK government commissioned consultants KPMG in 1999 to undertake a report reviewing the OTs' compliance with international standards and best practice in financial regulation. The report recommended a number of proposals that the OTs agreed to implement. The key measures were the establishment of independent regulatory authorities, the introduction 
of investigative powers to assist enquiries by overseas regulators and the creation of comprehensive anti-money laundering frameworks (KPMG, 2000).

It is important to recognise, however, that bi-lateral efforts involving the UK and the OTs to improve regulatory oversight of the offshore financial sector have not been carried out in a vacuum. International demands for greater control over offshore finance have also been very important with the involvement of organisations such as the Financial Action Task Force (FATF) which promotes policies to combat money laundering and terrorist financing; the Financial Stability Board (formerly the Financial Stability Forum) which promotes the implementation of effective regulatory and supervisory policies; the International Monetary Fund via its Financial Sector Assessment Programme; the European Union (EU) via its savings tax directive; and the Organisation for Economic Cooperation and Development (OECD) formerly through its 'Harmful Tax Competition Initiative' (HTCI) and more recently via its Global Forum and 'internationally agreed tax standard' to encourage financial centres to share information with tax authorities. The level of oversight over the offshore financial sector is thus now substantive, but in several cases the process of adopting new regulation has been controversial. For example, in relation to the ultimately unsuccessful HTCI, Persaud argued: 'Rule-making by the OECD for non-OECD states is of questionable international legality' (Persaud, 2001: 202), while Sanders called the OECD action the 'usurpation of global governance' (Sanders, 2003: 6). Further, the Cayman Islands raised 'holy hell' about the lack of consultation over the EU savings tax directive (FAC, 2008: 46). 


\section{Regulatory standards today}

It is clear that the UK government has taken a significant interest in the territories' financial service industries. As a consequence the OTs are largely compliant with the key international regulatory regimes. For example, all territories meet the OECD's internationally agreed tax standard and in addition improvements have made been in the regulatory environment more generally. For example, the size of the regulatory authority in each territory has generally been on a rising trend. Bermuda and Gibraltar have more than doubled the number of staff employed since 2002, whilst the British Virgin Islands has increased staff resources by more than 60 per cent (Foot, 2009: 41). The NAO commended these changes as 'major improvements' (2007: 21).

However, as the IMF's Financial Sector Assessment Programme highlights, there are still improvements to be made, both in terms of delivering effective regulation in banking, insurance and securities and in fighting financial crime. For example, Gibraltar in 2007 and Bermuda in 2008 were assessed as needing to do more in order to meet particular FATF recommendations (IMF 2007, 2008). Further, concerns have been raised about the limited number of suspicious transaction reports (particularly in Anguilla, British Virgin Islands, and TCI) and the low level of prosecutions for finance related crime (for example, there was just a single money laundering prosecution in Bermuda in 2008) (Foot, 2009: 53, 55; NAO, 2007).

Nevertheless, the larger territories are doing better than the smaller ones. As the NAO found Bermuda, British Virgin Islands, Cayman Islands and Gibraltar were 'leaving in 
their wake the weaker regulatory capacity' of Anguilla, Montserrat and TCI (NAO, 2007: 5). As Foot argues the scope for improvement 'is most evident in the smaller Territories, where compliance costs bear most heavily because of a lack of economies of scale and the difficulty of attracting staff with the necessary expertise' (2009: 39). This is particularly true for Anguilla and TCI, both of whom employ less than 10 staff to supervise financial services providers. It is argued this is below the 'critical mass' to keep up with the ever-evolving international regulatory framework (NAO, 2007: 6; Foot, 2009: 41). This is worrying as the Governor retains direct responsibility for the regulation of international finance in these small territories. Indeed, mirroring the criticisms made in relation to safeguarding good governance, it can be argued that the UK government via its governors has not been sufficiently engaged in overseeing good practice in the offshore financial industries of the smallest territories, despite the enactment of high-profile reforms such as the EU savings tax directive. As the Committee of Public Accounts (CPA) noted, the 'Governors have not used their reserve powers to rectify [weak investigative capacity]' and the UK has been 'complacent' in not acting more decisively (CPA, 2008: 5).

Although the OTs are making attempts to comply with global standards of financial regulation there are still concerns that small jurisdictions lack the necessary resources for proper supervision. Bermuda, British Virgin Islands and Cayman Islands are small countries with large financial sectors in proportion to their size and this remains problematic in terms of proper oversight of the industry. Presently Cayman Islands is listed on the US State Department's list of countries of primary concern in relation to 
money laundering (US State Department, 2010). Further, the then US-presidential candidate Barack Obama made specific mention of Cayman Islands and its role in alleged tax evasion. Obama stated: 'There's a building in the Cayman Islands that houses supposedly 12,000 US-based corporations [referring to Ugland House, the Cayman Islands' office of law firm, Maples and Calder]. That's the biggest building in the world of the biggest tax scam in the world, and we know which one it is' (The Guardian, 2009). Despite such concerns a recent report commissioned by the UK government to review the UK's offshore financial centres said little on these matters (Foot, 2009). As a consequence, there is no threat to the OTs' offshore financial sector in the foreseeable future. Nevertheless, it can be argued that regulation of the offshore financial service industries in the OTs has been patchy since the White Paper particularly so for the smaller jurisdictions - and this is troubling.

\section{Sustainable economic development}

Over much of the last decade there is no doubt that many OTs have experienced rapid economic growth. For example, real GDP growth in Bermuda averaged 4.4 per cent a year between 2003 and 2007, while in Gibraltar growth in 2008/9 was estimated at 6 per cent (Foot, 2009: 25). Growth in the Caribbean territories has also been strong. This in turn has consolidated the territories' excellent GDP per capita figures. Bermuda, for example, had a GDP per capita of US\$91,477 in 2007 (Bermuda Department of Statistics, 2009: 7), while Cayman Islands had a GDP per capita of US\$57,016 in the same year (Cayman Islands Economics and Statistics Office, 2009). However, in the last couple of years the effects of the global economic downturn have impacted very 
heavily on many OTs and this has undermined the UK's stated aim in the White Paper to 'help [the OTs] achieve sustainable development' through 'sensible economic and financial management' (FCO, 1999: 30).

Despite the OTs relatively high levels of economic development most rely on a few key industries - particularly financial services, tourism and construction - for both government revenue and employment. The proportion of government revenue generated by financial services and tourism is approximately 50 per cent for the majority of territories, whilst they account for between 23 per cent and 48 per cent of employment (Foot, 2009: 23). The vulnerability of government revenue is particularly acute since the Caribbean territories and Bermuda have a narrow revenue base. There are no taxes levied on income, profits and capital gains, nor are there sales or value added taxes. Rather revenue is derived from a combination of import duties, financial sector licence fees and other specific charges (Foot, 2009: 24). Thus many OT economies are 'particularly exposed to economic shocks' (Foot, 2009: 25). The one exception to this is Gibraltar because it has one of the most diversified economies amongst the territories, with income from shipping, tourism, financial services, and internet gaming. In addition the Falklands economy continues to diversify, with greater emphasis on tourism and commercial fishing and the future possibility of oil extraction.

The Caribbean territories and Bermuda have suffered during the recession from reduced activity in their financial services sector and declines in tourist arrivals and construction. For example, in the British Virgin Islands new international business 
company incorporations fell by 44 per cent between September and December 2008 compared to the same period in 2007, while Anguilla and the Cayman Islands suffered declines in tourist arrivals in 2009 of 22.6 per cent and 10.2 per cent respectively (Foot, 2009: 26; Caribbean Tourism Organisation, 2010). Therefore the negative impact on public finances has been significant, particularly for Anguilla, Cayman Islands, and TCI (the latter's situation being exacerbated by the previous government's corruption and mismanagement). In response the UK has shown a new determination help correct the structural imbalances in the OT economies and this is of course welcome and necessary. However, it is unfortunate the UK waited so long to act despite the commitments enshrined within the White Paper. It can be argued that the impressive levels of economic growth during the mid-2000s helped to hide the serious structural problems present in the OT economies and as a consequence the UK felt that any reforms could be delayed. Unfortunately the shortcomings of this approach can now be seen.

One further example that illustrates the impact of the recent global economic downturn on the economic development of the OTs is the case of St Helena, the second poorest of the territories in terms of GDP per capita (NAO, 2007: Appendix 2). For many years the principal link with the isolated island, which is $2,000 \mathrm{~km}$ from its nearest neighbour, has been the ageing supply and passenger vessel RMS St Helena, which calls at the island from the UK twice a year and is due to be withdrawn from service. After several years of lobbying DFID agreed in 2005 that St Helena should have its own airport within five years as an essential means of attracting inward investment, enabling the island to develop its economy - including tourism - and to offset its limited natural resources, 
high import dependency, relatively large public sector and outward migration.

However, in December 2008 DFID decided to freeze the airport plan in view of the economic climate and took the opportunity to consider potential savings to the airport contract and a possible public private partnership (Hansard, 2009b). This decision was reversed by the Coalition Government on 22 July 2010 when the Secretary of State for International Development announced that 'provided certain conditions are met, the best long-term solution from an economic and financial perspective for both HMG and St Helena is to construct an airport' (Hansard, 2010). Provided that this decision is followed through, the population decline noted by the NAO (2007: 55) may eventually be halted and the current level of aid - $£ 35.7$ million in bilateral aid in 2008/9 - will ultimately be reduced.

Beyond the broad economic vulnerabilities of the OTs, concerns have also been raised about the inadequate financial procedures and controls in place. In its 2007 report the NAO highlighted the fact that many territories 'have difficulty producing timely, audited public accounts' and most significantly suggested 'the situation appears much the same as it was ten years ago, when half of populated Territories were two years or more "behind"' (NAO, 2007: 31). The NAO also stated that 'a capable external audit function is not seen as a priority by all Territory governments' (2007: 31). For example, staffing levels in the Auditor General's office in the British Virgin Islands was one-third below complement in 2007 (NAO, 2007: 31). There were also concerns over the independence of audit officers. To overcome such problems both Anguilla and the Falkland Islands have their accounts audited by external agencies. Other difficulties were highlighted more recently in the Foot report. Foot noted 'the absence of timely and 
reliable data and of the expertise to analyse [economic] trends' (Foot, 2009: 29). He also criticised the 'weaknesses in data quality' (idem) in some territories. For example, Anguilla, Cayman Islands and TCI overestimated significantly their expected revenue take during 2008-09 (Foot, 2009: 29). The weaknesses in data quality and auditing procedures have largely been left unattended since the White Paper. If they had been corrected the worst effects of the global economic downturn might have been mitigated.

\section{Conclusions and recommendations}

The 1999 White Paper set out a clear, necessary and generally comprehensive plan of action to improve the governing arrangements between the UK and its OTs. However, the results 10 years on have been only partially successful. There are three main reasons for this. First, the nature of the relationship remains very complex and dynamic which provides continuous challenges for the UK government, the governors and the local territory governments to overcome. Second, governors' powers remain limited in several respects and this inhibits the UK government's ability to deal with problems in the OTs. Third, the UK government and the OT governments failed to act with due care and attention when it came to properly maintaining the relationship. The UK did not fully engage and intervene in the OTs even when its interests were at stake, while in many cases the territories (particularly those in the Caribbean) showed a disregard for maintaining the highest standards of good governance and financial probity - illustrated recently and most clearly in the TCI. So in light of these problems, what improvements should be made to the relationship over the next decade? 
First, links between the UK and the OTs should be strengthened, deepened and in some areas made more nuanced. Thus we endorse the view taken by the FAC who suggested that the partnership concept between the UK and the OTs must be based on something more than an annual meeting of the Overseas Territories Consultative Committee (OTCC) and who argued that 'properly consulting and representing the OTs on issues that affect them is an important part of creating the type of "modern partnership" which may prevent the need for direct intervention' (2008: 130). This would also mean more varied approaches and policies to deal with the diversity amongst the territories. In addition, there should be more regular consultation by the UK government with the OT representatives based in London, as well as greater openness in publishing documents and reporting on meetings of the OTCC. In addition, the FAC's recommendation that governors of the OTs ought to use their reserve powers to bring in more external investigators or prosecutors to strengthen investigative capacity (2008: 98) should be implemented. Indeed, the UK's entire approach towards the OTs must be more consistently pro-active than before. However, there are worrying signs in regard to the TCI that the UK is still reluctant to use all its available powers and to undertake all the necessary reforms to clean up the political system. If the UK fails in its task it will be a dereliction of its duty and risks 'undermining its own credibility in its use of reserved powers in not just the TCI but in the other Overseas Territories' (Foreign Affairs Committee, 2010: 13).

Second, the position of the UK government and its governors must be strengthened. For example, there should be greater continuity in the appointment of ministers responsible 
for the OTs and a requirement that the incumbent holds fewer responsibilities so that they can devote more time to the territories. Further, the process of familiarising newly appointed governors with the OTs should be reinforced and OT administration and governance should be developed as a distinct specialism and career path within Whitehall.

Third, there needs to be better sharing of information and good practice across the OTs via cross-Territory training and conferences and support for short term secondments and personnel exchange. Importantly, this training, and support must be overtly focused on specific objectives. Above all, the development of a stronger culture of integrity in the OTs is a necessity, otherwise any initiatives will come to nought.

Clearly, further change is needed if the objectives of the 1999 White Paper are to be finally met. However, the recent spending cuts announced by the new Conservative-led coalition government will not make real reform any easier to achieve. The FCO's budget is scheduled to be cut, and this could impact negatively on the administrative and financial support given to the OTs. It is true that DFID's budget will increase but its main interests lie not with the territories. Under such circumstances the UK's level of engagement with the OTs may well decline. The key message emerging from this paper is that this would be a mistake, and potentially a costly one. The failure to maintain and more importantly improve standards of governance in the territories would undoubtedly lead to increased financial and legal liabilities in the future. 


\section{References}

Bermuda Department of Statistics (2009) Facts and Figures 2009. Available at www.gov.bm/portal/server.pt/gateway/PTARGS_0_2_980_227_1014_43/http\%3B/ptp

ublisher.gov.bm\%3B7087/publishedcontent/publish/cabinet_office/statistics/dept__sta tistics__additonal_files/articles/facts_and_figures_2009_0.pdf (accessed 31 March 2010).

Caribbean Insight (2008) 'UK MPs Express Concern Over Turks and Caicos', 31(12), 31 March (London: Caribbean Council).

Caribbean Tourism Organisation (2010) Latest Statistics 2009. Available at www.onecaribbean.org/content/files/March242010Lattab09.pdf (accessed 31 March 2010).

The Cayman Islands Constitution Order 2009, Statutory Instrument No. 1379, Office of Public Sector Information. Available at www.opsi.gov.uk/si/si2009/uksi_20091379_en_1 (accessed 25 March 2010).

Cayman Islands Economics and Statistics Office (2009) Statistical Compendium: The Cayman Islands at a glance. Available at www.eso.ky/docum1/docum85.pdf (accessed 31 March 2010). 
Committee of Public Accounts (1998) Foreign and Commonwealth Office: Contingent Liabilities in the Dependent Territories, Thirty-Seventh Report, House of Commons, 11 May (London: The Stationary Office).

Committee of Public Accounts (2008) Foreign and Commonwealth Office: Managing Risk in the Overseas Territories, Seventeenth Report, House of Commons, 31 March (London: The Stationary Office).

Davies, E. (1995) The Legal Status of British Dependent Territories: The West Indies and North Atlantic Region (Cambridge: Cambridge University Press).

Department for International Development (1999) An Evaluation of HMG's Response to the Montserrat Volcanic Emergency, Volume 1, EV635, December (London: The Stationary Office).

Financial Times (2009) 'Anti-corruption team sent to Turks \& Caicos', 25 August.

Foot, M. (2009) Final report of the independent Review of British offshore financial centres, October (London: Office of Public Sector Information).

Foreign Affairs Committee (2004) 'Overseas Territories: Written Evidence’, HC 114, House of Commons, March (London: The Stationary Office). 
Foreign Affairs Committee (2008) Overseas Territories, House of Commons, Seventh Report of Session 2007-08, HLC 147-1, July (London: The Stationary Office).

Foreign Affairs Committee (2010) Turks and Caicos Islands, Seventh Report of Session 2009-10, HC469, March (London: The Stationary Office).

Foreign and Commonwealth Office (1999) Partnership for Progress and Prosperity:

Britain and the Overseas Territories, $\mathrm{Cm}$ 4264, March (London: The Stationary Office).

Foreign and Commonwealth Office (2009) 'A major step in clean up of public life in Turks and Caicos', 14 August. Available at http://www.fco.gov.uk/en/newsroom/latestnews/?view=News\&id=20700728 (accessed 9 September 2009).

Guardian, The (2009) 'Brown targets Switzerland in global tax haven crackdown', 19 February.

Hansard (2009a) 'Written Ministerial Statement - Turks and Caicos Islands: Governance', Columns 39-40WS, 16 March.

Hansard (2009b) 'Written Ministerial Statement - St Helena', Columns 114-115WS, 15 December. 
Hansard (2010) 'Written Ministerial Statement - St Helena (Access)', Columns 4647WS, 22 July.

Human Rights Watch (2009) 'Cayman Islands: Ensure Equality for All', 11 March. Available at www.hrw.org/en/news/2009/03/11/cayman-islands-ensure-equality-all (accessed 31 March 2010).

International Development Committee (1997) Montserrat, First Report, House of Commons, 18 November (London: The Stationary Office).

International Development Committee (1998) Montserrat - Further Developments, Sixth Report, House of Commons, 28 July (London: The Stationary Office).

International Monetary Fund (2007) Gibraltar: Assessment of Financial Sector Supervision and Regulation including Reports on the Observance of Standards and Codes on the following topics: Banking Supervision, Insurance Supervision, and AntiMoney Laundering and Combating the Financing of Terrorism. IMF Country Report No. 07/154, May 2007 (IMF: Washington DC).

International Monetary Fund (2008) Bermuda: Assessment of Financial Sector Supervision and Regulation. IMF Country Report No. 08/336, October 2008 (IMF: Washington DC). 
KPMG (2000) Review of the financial regulation in the COTs and Bermuda, Cm 4855

(London: Foreign and Commonwealth Office).

National Audit Office (1997) Foreign and Commonwealth Office: Contingent

Liabilities in the Dependent Territories, Report by the Comptroller and Auditor

General, HC 13 1997/98, 30 May (London: The Stationary Office).

National Audit Office (2007) Foreign and Commonwealth Office: Managing Risk in the Overseas Territories, Report by the Comptroller and Auditor General, HC 4 2007-2008, 16 May (London: The Stationary Office).

Persaud, B. (2001) OECD Curbs on Offshore Financial Centres: A Major Issue for Small States, The Round Table, 359, pp. 199-212.

Report of the Commissioner Mr Louis Blom-Cooper QC, into Allegations of Arson of a Public Building, Corruption and Related Matters, December 1986 (London: HMSO).

Sanders, R. (2003) The War Against Terror and the Erosion of Rights (London, Hansib Publications).

Taylor, D. (2000) British Colonial Policy in the Caribbean: The Insoluble Dilemma the Case of Montserrat, The Round Table, 355, pp. 337-344. 
Taylor, D. (2005) The British Overseas Territories in the Caribbean: Recent History and Current Policy, in: D. Killingray \& D. Taylor (Eds) The United Kingdom Overseas Territories: Past, Present and Future, pp. 19-23 (London, Institute of Commonwealth Studies).

Turks and Caicos Islands Commission of Inquiry 2008-2009, Report of the Commissioner The Right Honourable Sir Robin Auld. Available at http://www.fco.gov.uk/en/newsroom/latest-news/?view=News\&id=20700728 (accessed 9 September 2009).

US State Department (2010) International Narcotics Control Strategy Report, Volume II: Money Laundering and Financial Crimes. Available at www.state.gov/p/inl/rls/nrcrpt/2010/vol2/index.htm (accessed 31 March 2010).

The Virgin Islands Constitution Order 2007, Statutory Instrument No. 1678, Office of Public Sector Information. Available at www.opsi.gov.uk/si/si2007/uksi_20071678_en_1 (accessed 1 July 2009). 